\title{
Epidemiological, neurofunctional profile and prevalence of factors associated with the occurrence of physical disabilities due to leprosy in a reference center in Northeast Brasil: a sectional study
}

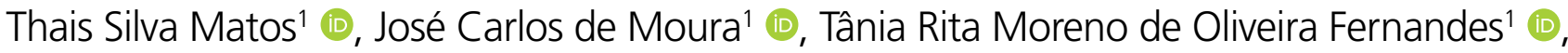 \\ Carlos Dornels Freire de Souza ${ }^{2 *}$
}

\section{SUMMARY}

OBJECTIVE: To describe the epidemiological and neurofunctional profile, as well as the prevalence of factors associated with the occurrence of physical disabilities due to leprosy in a reference center in Northeast Brasil.

METHODS: A cross-sectional study including 50 leprosy patients diagnosed in Juazeiro-Bahia. Variables analyzed: sex, age, history of leprosy in the family, time to diagnosis, clinical form, operational classification, degree of disability, eyes-hand-foot score, peripheral nerve function, muscle strength and sensitivity. Descriptive statistics and inferential statistics $\left(\chi^{2}\right.$ test or Fisher's exact, Poisson regression with robust estimation and prevalence reason were used. Significance of 5\%).

RESULTS: An equal distribution was found between men and women of economically active age and low education; multibacillary forms in men (64\%) and paucibacillary forms in women (60\%). $78 \%$ of individuals had some degree of disability and $64 \%$ had a compromised ulnar nerve. Plantar sensitivity was decreased in $66 \%$ of patients. The predictors of disability were: age $\geq 45$ years (PR 1.44; $p=0.005)$, no education (PR 1.21; $\mathrm{p}=0.013$ ) and OMP score $\geq 6$ (PR 1.29; $\mathrm{p}<0.001$ ).

CONCLUSION: The findings show the importance of monitoring neural functions and developing measures that allow early diagnosis, the opportune method and the prevention of disabilities, especially in the male population.

KEYWORDS: Leprosy. Neurology. Disabled persons. Prevalence. Epidemiology.

\section{INTRODUCTION}

Leprosy is a chronic granulomatous infectious disease, caused by Mycobacterium leprae. The bacillus has a predilection for peripheral nerves and cutaneous attachments, which can result in physical disabilities when not diagnosed early or not properly treated ${ }^{1}$. It is estimated that about 3 million people experience physical disabilities due to leprosy worldwide ${ }^{2}$.

Concern with the consequences caused to people affected by the disease led the World Health Organization (WHO) to implement, in the year 2016, the Global Leprosy Strategy 20162020: acceleration towards a leprosy-free world, which aims to

i) reduce to zero the number of children with leprosy;

ii) reduce the rate of new cases with visible deformities to less than one person per million inhabitants and

iii) reduce discrimination caused by the disease ${ }^{3}$.

Because of the relationship leprosy has with the functionality of affected individuals, the evaluation and systematic monitoring of neural functions and the Degree of Physical

\footnotetext{
'Universidade Federal do Vale do São Francisco - Petrolina (PE), Brasil.

¿Universidade Federal de Alagoas - Arapiraca (AL), Brasil.

*Corresponding author: carlos.freire@arapiraca.ufal.br

Conflicts of interest: the authors declare there are no conflicts of interest. Funding: none.

Received on June 8, 2020. Accepted on September 20, 2020.
} 
Disability (GIF) are necessary in all cases of leprosy, in at least two moments: the diagnosis and the discharge for cure ${ }^{3}$, given that the presence of nerve damage and disability are important indicators of late diagnosis of the disease and transmission chain maintenance in the community ${ }^{4}$.

The simplified neurological evaluation includes the identification of complaints in eyes, hands and feet (OMP), palpation of peripheral nerves, evaluation of sensitivity through the stoichiometric examination and evaluation of motor skills. After the neurological examination, a degree of physical disability is assigned, ranging from 0 to 2: Degree 0 - Muscle strength and sensitivity preserved in the eyes, hands and feet; Degree 1 - Muscle strength and sensitivity decreased in eyes, hands and/or feet; Degree 2 - Visible deficiencies caused by leprosy in eyes, hands and/or feet (lagophthalmos, ectropion, trichiasis, corneal opacity, claws, muscular atrophy, bone resorption, wounds and contractures) $)^{5}$.

The city Juazeiro (Bahia, Brasil), the studied area, registered 126 new cases in 2017, thus occupying the second position in absolute number of cases, behind only the state of Bahia's capital Salvador (299 registered cases). The municipal detection rate was $58.8 / 100,000$, which classifies the municipality as having hyperendemic transmission $(\geq 40$ cases/100,000 inhabitants) ${ }^{6}$.

Given the above, this study aimed to describe the epidemiological, neurofunctional profile and the prevalence of factors associated with the occurrence of physical disabilities in new cases of leprosy in a reference center in Northeast Brasil.

\section{METHODS}

\section{Study design and location}

This was a cross-sectional observational study, carried out at the reference center of Dr. Altino Lemos Santiago, located in Juazeiro, state of Bahia, whose estimated population for the year 2018 was 215 thousand inhabitants ${ }^{7}$. The municipality registers an annual average of 95 new cases of leprosy, and it is considered a priority municipality for leprosy.

\section{Studied population}

A nonprobabilistic sample consisting of 50 individuals newly diagnosed with leprosy at the referral center was adopted. The following inclusion criteria were adopted: only newly diagnosed cases, residing in the studied municipality and who did not have any other neurological disease. It should be noted that 58 individuals were invited to participate in the research, out of which eight refused.

\section{Study variables and collection procedures}

The collection was carried out between January and June 2018, and took place using two forms recommended by the Ministry of Health of Brasil: the first was used to collect sociodemographic and clinical characteristics, based on patient information and specialized medical evaluation (sex, age group, education, clinical form, operational classification, time until diagnosis and history of leprosy in the family); and the second was used for simplified neurological assessment and evaluation of the degree of disability, according to a model standardized by the Ministry of Health ${ }^{5}$. From this second form, the following variables were collected: palpation of peripheral nerves, muscle strength, sensitivity test (esthesiometry), degree of physical disability (total and second body part) and eyes, hands and feet score (OMP score).

It should be noted that data collection was performed by a physical therapist right after the medical diagnosis. Initially, the research objectives were explained and the informed consent form was signed (ICF), followed by neurological assessment.

\section{Statistical treatment}

After collection, data was entered into an electronic spreadsheet and analyzed using the Statistical Package for the Social Sciences - SPSS software, version 22.0 (SPSS, Inc., Chicago, IL). Descriptive (absolute and relative frequencies) and inferential ( $Z$ test with Bonferroni correction, $\chi^{2}$ test or Fisher's exact test, Poisson regression with robust estimation and prevalence ratio - PR) statistics were used. For the identification of factors associated with the presence of physical disability, some polytomous variables were dichotomized: age group $(<45$ and $\geq 45$ years), education (illiterate and some education) OMP score ( $<6$ and $\geq 6$ ) and time until diagnosis ( $<12$ and $\geq 12$ months). A $95 \%$ confidence interval and a 5\% significance level were adopted.

\section{Ethical aspects}

The study was approved by the Research Ethics Committee of the Federal University of Vale do São Francisco (UNIVASF): see No. 1905873/2017.

\section{RESULTS}

Of the 50 individuals diagnosed with leprosy in the reference center Dr. Altino Lemos Santiago, 50.0\% were female. With regard to sociodemographic characteristics, the age group between 30 and 44 years old stood out (40.0\% of men and $32.0 \%$ of women were located in this age group), with no significant difference between sexes. Low education was another remarkable feature: $80.0 \%(n=20)$ of men and $64.0 \%(n=16)$ of women were illiterate or had only primary education (Table 1 ). 
Table 1. Sociodemographic and epidemiological characterization of new leprosy cases diagnosed at the Dr. Altino Lemos Santiago reference center - Juazeiro, Bahia, 2018.

\begin{tabular}{|c|c|c|c|c|c|}
\hline & \multicolumn{2}{|c|}{$\begin{array}{c}\text { Male } \\
25(50 \%) \\
\end{array}$} & \multicolumn{2}{|c|}{$\begin{array}{c}\text { Female } \\
25(50 \%)\end{array}$} & \multirow[t]{2}{*}{$\mathrm{p}$-value } \\
\hline & $\mathrm{n}$ & $\%$ & $\mathrm{n}$ & $\%$ & \\
\hline \multicolumn{6}{|c|}{ Age group (in years) } \\
\hline $0-14$ & 0 & 0.0 & 2 & 8.0 & \multirow{5}{*}{$0.582^{\mathrm{a}}$} \\
\hline $15-29$ & 2 & 8.0 & 3 & 12.0 & \\
\hline $30-44$ & 10 & 40.0 & 8 & 32.0 & \\
\hline $45-59$ & 9 & 36.0 & 6 & 24.0 & \\
\hline 60 or more & 4 & 16.0 & 6 & 24.0 & \\
\hline
\end{tabular}

Education

\begin{tabular}{|l|c|c|c|c|}
\hline Illiterate & 3 & 12.0 & 2 & 8.0 \\
\hline Incomplete elementary school & 13 & 52.0 & 13 & 52.0 \\
\hline Complete primary education & 4 & 16.0 & 1 & 4.0 \\
\hline Incomplete high school & 0 & 0.0 & 3 & 12.0 \\
\hline Complete high school & 5 & 20.0 & 2 & 8.0 \\
\hline Incomplete higher education & 0 & 0.0 & 2 & 8.0 \\
\hline Complete higher education & 0 & 0.0 & 2 & 8.0 \\
\hline
\end{tabular}

Clinical form

\begin{tabular}{l|c|c|c|c}
\hline Indeterminate & 2 & 8.0 & 4 & 16.0 \\
\hline Tuberculoid & 7 & 28.0 & 11 & 44.0 \\
\hline Dimorfa & 11 & 44.0 & 10 & 40.0 \\
\hline Virchowiana & 5 & 20.0 & 0 & 0.0 \\
\hline
\end{tabular}

Operational classification

\begin{tabular}{l|c|c|c|c|c}
\hline Paucibacilar & 9 & 36.0 & 15 & 60.0 & \multirow{2}{*}{$0.089^{\mathrm{b}}$} \\
\hline Multibacillary & 16 & 64.0 & 10 & 40.0 & \\
\hline
\end{tabular}

Degree of physical disability

\begin{tabular}{|c|c|c|c|c|c|}
\hline Degree 0 & 6 & 24.0 & 5 & 20.0 & \multirow{3}{*}{$0.047^{a}$} \\
\hline Degree 1 & 8 & 32.0 & 16 & 64.0 & \\
\hline Degree 2 & 11 & 44.0 & 4 & 16.0 & \\
\hline \multicolumn{6}{|c|}{ History of Leprosy in the Family } \\
\hline Yes & 10 & 40.0 & 12 & 48.0 & \multirow{2}{*}{$0.569^{b}$} \\
\hline No & 15 & 60.0 & 13 & 52.0 & \\
\hline \multicolumn{6}{|c|}{ Time until diagnosis } \\
\hline$\geq 12$ months & 8 & 32.0 & 14 & 56.0 & \multirow{2}{*}{$0.087^{b}$} \\
\hline$<12$ months & 17 & 68.0 & 11 & 44.0 & \\
\hline
\end{tabular}

${ }^{\mathrm{a} p}$-value by Fisher's exact test; ${ }^{\mathrm{b}} \mathrm{p}$-value by $\chi^{2}$ test.

There was a predominance of the dimorphic form in the males and of tuberculoid form in females $(44.0 \%$ and $44.0 \%$, respectively). All of virchowian cases $(\mathrm{n}=5)$ were observed in men. $64.0 \%(n=16)$ of men had multibacillary forms and $60.0 \%$ $(n=15)$ of women had paucibacillary forms. $80.0 \%(n=20)$ of women and $76.0 \%(n=19)$ of men had some physical disability, with degree 2 associated with the male population and degree 1 with the female population $(\mathrm{p}=0.047)$ (Table 1$)$. 
Table 2. Simplified neurological assessment in new cases of leprosy diagnosed at the Dr. Altino Lemos Santiago reference center - Juazeiro, Bahia, 2018.

\begin{tabular}{|c|c|c|c|c|c|c|c|c|}
\hline \multicolumn{9}{|c|}{ A - Palpation of peripheral nerves } \\
\hline Nerve & \multicolumn{2}{|c|}{$\begin{array}{c}\text { Normal } \\
\mathrm{n}(\%)\end{array}$} & \multicolumn{2}{|c|}{$\begin{array}{c}\text { Thickening } \\
\mathrm{n}(\%)\end{array}$} & \multicolumn{2}{|r|}{$\begin{array}{l}\text { Pain } \\
\mathrm{n}(\%)\end{array}$} & \multicolumn{2}{|c|}{$p$-value ${ }^{a}$} \\
\hline Ulnar & \multicolumn{2}{|c|}{$18(36.0)$} & \multicolumn{2}{|c|}{$31(62.0)$} & \multicolumn{2}{|r|}{$1(2.0)$} & \multicolumn{2}{|c|}{$<0.001$} \\
\hline Median & \multicolumn{2}{|c|}{$37(74.0)$} & \multicolumn{2}{|c|}{$2(4.0)$} & \multicolumn{2}{|c|}{$11(22.0)$} & \multicolumn{2}{|c|}{$<0.001$} \\
\hline Radial & \multicolumn{2}{|c|}{$32(64.0)$} & \multicolumn{2}{|c|}{$1(2.0)$} & \multicolumn{2}{|c|}{$17(34.0)$} & \multicolumn{2}{|c|}{$<0.001$} \\
\hline Fibular & \multicolumn{2}{|c|}{$28(56.0)$} & \multicolumn{2}{|c|}{$11(22.0)$} & \multicolumn{2}{|c|}{$11(22.0)$} & \multicolumn{2}{|c|}{0.003} \\
\hline Tibial & \multicolumn{2}{|c|}{$34(68.0)$} & \multicolumn{2}{|c|}{$6(12.0)$} & \multicolumn{2}{|c|}{$10(20.0)$} & \multicolumn{2}{|c|}{$<0.001$} \\
\hline \multicolumn{9}{|c|}{ B - Assessment of muscle strength } \\
\hline \multicolumn{3}{|c|}{ Muscle / Muscle group } & \multicolumn{2}{|c|}{$\begin{array}{c}\text { Paralyzed } \\
\mathrm{n}(\%)\end{array}$} & \multicolumn{2}{|c|}{$\begin{array}{c}\text { Decreased } \\
\text { n (\%) }\end{array}$} & $\begin{array}{l}\text { Strong } \\
\mathrm{n}(\%)\end{array}$ & $p$-value \\
\hline \multicolumn{3}{|c|}{ 5th finger abductor (ulnar nerve) } & \multicolumn{2}{|c|}{$0(0.0)$} & \multicolumn{2}{|c|}{$12(24.0)$} & $38(76.0)$ & $<0.001$ \\
\hline Thumb abductc & (median ner & & & & & $9(18.0)$ & $41(82.0)$ & $<0.001$ \\
\hline Wrist extenders & radial nerve) & & & & & $5(10.0)$ & $45(90.0)$ & $<0.001$ \\
\hline Hallux extensio & (fibular nerv & & & & & $6(12.0)$ & $44(88.0)$ & $<0.001$ \\
\hline Hallux dorsiflex & s (fibular ne & & & & & $4(8.0)$ & $46(92.0)$ & $<0.001$ \\
\hline & & $C-$ & nsitivity ev & uation (Es & esiometr & & & \\
\hline Nerve & $\begin{array}{l}0.05 \mathrm{~g} \\
\mathrm{n}(\%)\end{array}$ & $\begin{array}{l}0.2 \mathrm{~g} \\
\mathrm{n}(\%)\end{array}$ & $\begin{array}{l}2.0 \mathrm{~g} \\
\mathrm{n}(\%)\end{array}$ & $\begin{array}{l}4.0 \mathrm{~g} \\
\mathrm{n}(\%)\end{array}$ & $\begin{array}{c}10 \mathrm{~g} \\
\mathrm{n}(\%)\end{array}$ & $300 \mathrm{~g}(\%)$ & Total loss & $p$-value \\
\hline Median & $12(24.0)$ & $16(32.0)$ & $16(32.0)$ & $3(6.0)$ & $1(2.0)$ & $0(0.0)$ & $2(4.0)$ & $<0.001$ \\
\hline Ulnar & $14(28.0)$ & $15(30.0)$ & $14(28.0)$ & $4(8.0)$ & $1(2.0)$ & $1(2.0)$ & $1(2.0)$ & $<0.001$ \\
\hline Radial & $11(22.0)$ & $20(40.0)$ & $16(32.0)$ & $3(6.0)$ & $0(0.0)$ & $0(0.0)$ & $0(0.0)$ & 0.005 \\
\hline Deep fibular & $0(0.0)$ & $12(24.0)$ & $18(56.0)$ & $9(18.0)$ & $0(0.0)$ & $0(0.0)$ & $1(2.0)$ & $<0.001$ \\
\hline Safeno & $5(10.0)$ & $8(16.0)$ & $25(50.0)$ & $7(14.0)$ & $3(6.0)$ & $1(2.0)$ & $1(2.0)$ & $<0.001$ \\
\hline Sural & $1(2.0)$ & $2(4.0)$ & $32(64.0)$ & $6(12.0)$ & $4(8.0)$ & $4(8.0)$ & $1(2.0)$ & $<0.001$ \\
\hline $\begin{array}{l}\text { Calcaneal } \\
\text { branch }\end{array}$ & $1(2.0)$ & $1(2.0)$ & $14(28.0)$ & $18(36.0)$ & $\begin{array}{c}4 \\
(14.0)\end{array}$ & $8(16.0)$ & $1(2.0)$ & $<0.001$ \\
\hline Medial plantar & $0(0.0)$ & $4(8.0)$ & $29(58.0)$ & $6(12.0)$ & $\begin{array}{c}5 \\
(10.0)\end{array}$ & $5(10.0)$ & $1(2.0)$ & $<0.001$ \\
\hline Lateral plantar & $0(0.0)$ & $3(6.0)$ & $32(64.0)$ & $6(12.0)$ & $4(8.0)$ & $4(8.0)$ & $1(2.0)$ & $<0.001$ \\
\hline
\end{tabular}

aZ test for comparison of proportions with Bonferroni correction.

The most commonly thickened nerves were ulnar and fibular, at $62.0 \%(\mathrm{n}=31)$ and $22.0 \%(\mathrm{n}=11)$ of patients, respectively. Pain on palpation of the radial was present in $34.0 \%(\mathrm{n}=17)$ of the individuals evaluated and the muscular strength of the fifth finger abductor was reduced by $24.0 \%(\mathrm{n}=12)$ in the sample. In the esthesiometric examination, a greater sensory loss was observed in the lower limbs (Table 2). The regression model showed that the age group (PR 1.44; $\mathrm{p}=0.005$ ), the lack of education (PR 1.21; $\mathrm{p}=0.013)$ and the OMP score (PR 1.29; $\mathrm{p}<0.001)$ were associated with the presence of physical disabilities (Table 3). 
Table 3. Factors associated with the presence of physical disability in the diagnosis among leprosy cases diagnosed at the Dr. Altino Lemos Santiago reference center (Juazeiro/BA) in 2018.

\begin{tabular}{|c|c|c|c|c|c|c|}
\hline & \multirow{2}{*}{$\begin{array}{l}\text { Total } \\
\text { n (\%) }\end{array}$} & \multicolumn{2}{|c|}{ Physical Disability } & \multirow{2}{*}{$\mathrm{p}$-value } & \multirow{2}{*}{$\begin{array}{c}\text { Prevalence } \\
\text { ratio }\end{array}$} & \multirow{2}{*}{$95 \% \mathrm{Cl}$} \\
\hline & & Grade I or II & Grade 0 & & & \\
\hline \multicolumn{7}{|l|}{ Sex } \\
\hline Male & $25(50.0)$ & $19(48.7)$ & $6(54.5)$ & \multirow{2}{*}{0.543} & \multirow{2}{*}{1.12} & \multirow{2}{*}{$0.77-1.62$} \\
\hline Female & $25(50.0)$ & $20(51.3)$ & $5(45.5)$ & & & \\
\hline \multicolumn{7}{|l|}{ Age range* } \\
\hline$\geq 45$ & $27(54.0)$ & $24(61.5)$ & $3(27.3)$ & \multirow{2}{*}{0.005} & \multirow{2}{*}{1.44} & \multirow{2}{*}{$1.12-1.87$} \\
\hline$<45$ & $23(46.0)$ & $15(38.5)$ & $8(72.7)$ & & & \\
\hline \multicolumn{7}{|l|}{ Education* } \\
\hline Illiterate & $5(10.0)$ & $5(12.8)$ & $0(0.0)$ & \multirow{2}{*}{0.013} & \multirow{2}{*}{1.21} & \multirow{2}{*}{$1.04-1.41$} \\
\hline Some schooling & $45(90.0)$ & $34(87.2)$ & $11(100.0)$ & & & \\
\hline \multicolumn{7}{|c|}{ Operational Classification } \\
\hline Multibacillary & $26(52.0)$ & $22(56.4)$ & $4(36.4)$ & \multirow{2}{*}{0.238} & \multirow{2}{*}{1.14} & \multirow{2}{*}{$0.91-1.44$} \\
\hline Paucibacilar & $24(48.0)$ & $17(43.6)$ & $7(63.2)$ & & & \\
\hline \multicolumn{7}{|c|}{ Eyes, hands and feet score* } \\
\hline$\geq 6$ & $8(16.0)$ & $8(20.5)$ & $0(0.0)$ & \multirow{2}{*}{$<0.001$} & \multirow{2}{*}{1.29} & \multirow{2}{*}{$1.14-1.48$} \\
\hline$<6$ & $42(84.0)$ & $31(79.5)$ & $11(100)$ & & & \\
\hline \multicolumn{7}{|l|}{ Time until diagnosis } \\
\hline$\geq 12$ months & $22(44.0)$ & $18(46.2)$ & $4(36.4)$ & \multirow{2}{*}{0.515} & \multirow{2}{*}{0.921} & \multirow{2}{*}{$0.72-1.17$} \\
\hline$<12$ months & $28(56.0)$ & $21(53.8)$ & $7(63.6)$ & & & \\
\hline \multicolumn{7}{|c|}{ Family history of leprosy } \\
\hline Yes & $22(44.0)$ & $17(43.6)$ & $5(45.5)$ & \multirow{2}{*}{0.913} & \multirow{2}{*}{0.987} & \multirow{2}{*}{$0.78-1.24$} \\
\hline No & $28(56.0)$ & $22(56.4)$ & $6(54.5)$ & & & \\
\hline
\end{tabular}

*Significant association $(p<0.05)$.

\section{DISCUSSION}

The sociodemographic characteristics observed in relation to sex, age and education level corroborate the literature ${ }^{8}$. That is, leprosy is predominant in neglected populations ${ }^{9}$, with low education levels and in individuals of economically active age. All those are factors that can increase the process of social vulnerability and keep the leprosy transmission chain active in a given location ${ }^{10}$, generating a poverty-disease-poverty cycle, in which leprosy is both perpetuated and perpetuating ${ }^{11}$.

In our study, a homogeneous distribution was observed when analyzing the operational classification, although the proportion of multibacillary cases was slightly higher than that of paucibacillary cases. This result is lower than the national percentage $(65.1 \% \text { in } 2013)^{12}$. This finding should be viewed with concern, since the multibacillar cases are considered important in maintaining the chain of transmission of the disease ${ }^{4}$.

When comparing the sexes, the multibacillary forms were more present in men than in women, and all virchowians cases detected were diagnosed in the male population, indicating late diagnosis in this population group ${ }^{13}$. Studies on the subject highlight two determining factors for the occurrence of late diagnosis in men: less access to health services and neglect of the historical process of the male body ${ }^{13,14}$.

In this sense, late diagnosis and inadequate monitoring of patients are important factors that increase the risk of developing physical disabilities ${ }^{4,14}$. In our investigation, $78 \%$ of the evaluated cases already had some disability at the time of diagnosis. This percentage, evidenced in Juazeiro-BA, is similar to that observed in Aracaju-SE $(72.0 \%)^{15}$.

When stratifying according to sex, the male population had a degree 2 disability ratio 2.7 times greater than that of the female. This finding reinforces what we explained earlier in relation to late diagnosis in men. All this context signals the need for adoption of strategies and/or plans that enable the early detection, the timely treatment and the prevention of physical disabilities ${ }^{4,16}$.

Another factor associated with the occurrence of disabilities is age-related. In our study, individuals aged 45 years or 
older had a prevalence ratio (PR) 1, $44(\mathrm{p}=0.005)$ higher than the younger population, which corroborates the literature ${ }^{8}$. A recent investigation in Espírito Santo, involving the elderly population, showed that $39.9 \%$ of the cases diagnosed between 2001 and 2011 had physical disabilities $(28.6 \%$ with grade 1 and $11.3 \%$ with grade 2$)^{17}$.

The assessment of the degree of disability is one of the components of the simplified neurological examination, which also includes palpation of peripheral nerves and the assessment of muscle strength and sensitivity ${ }^{5}$. It was found that the ulnar nerve was the most affected, followed by the common fibular nerve, corroborating with the literature ${ }^{18,19}$. The ulnar nerve is responsible for the motricity of the abductor of the $5^{\text {th }}$ finger $^{19}$, whose strength was reduced in $24 \%$ of the population analyzed in this study. Additionally, Lugão ${ }^{20}$, from the ultrasound evaluation of the peripheral nerves of 100 patients with leprosy before and after multidrug treatment, showed that the most affected nerves were the common fibular (in paucibacillary leprosy) and the ulnar (in multibacillary form).

With regard to the assessment of sensitivity, the proportion of individuals with sensory impairment in the feet was almost three times greater than the proportion of patients with sensory loss in the hands. In addition, plantar ulcer was observed in four individuals (8\%). In research involving 414 patients at a reference center in João Pessoa-PB, 37.2\% ( $\mathrm{n}=154)$ of subjects had some involvement in the feet, which is the most affected region, highlighting the hypoesthesia and the ulcers, respectively ${ }^{21}$.

Many authors point out that patients with neuropathies have biomechanical imbalances in the lower limbs, which result in greater plantar pressure, thus predisposing the appearance of ulcers in these regions ${ }^{22,23}$. Gomes et al. ${ }^{23}$ showed that the risk of development of such ulcers relates to the clinic form the disease being elevated in patients with multibacillary leprosy. In this sense, we emphasize the importance of early intervention in order to prevent the occurrence of ulcers in individuals with leprosy.

Although leprosy is an endemic disease in Brasil, health services still face difficulties in the diagnosis and clinical management of diagnosed individuals ${ }^{16,18}$. In many municipalities, where there is no specialized referral center, there is a lack of trained professionals for the complete neurological assessment of patients who carry the risk of physical disabilities $^{10,24}$. We emphasize that the success of actions to prevent physical disabilities depends directly on the early identification of neural disorders.

Even considering the methodological thoroughness adopted, this study has limitations, with emphasis on the type of investigation conducted (cross-sectional study). In this sense, longitudinal investigations can help understand the evolution of neural injuries during treatment and after discharge. A second limitation concerns the sample size. Studies with larger and multicenter populations can elucidate questions that have not yet been answered regarding the neurological profile of individuals affected by leprosy in Brasil.

\section{CONCLUSIONS}

The epidemiological profile of leprosy was characterized by an equal proportion of men and women affected by the disease, predominance of young adult individuals, low education, multibacillary forms and the presence of physical disabilities at the time of diagnosis. Regarding the neurological profile, it was characterized by thickening predominantly in the ulnar and fibular nerves, pain on palpation of the radial nerve, muscle weakness in the abductor of the $5^{\text {th }}$ finger and sensory losses, predominantly in the lower limbs. The factors associated with the occurrence of physical disabilities were the age group $\geq 45$ years, lack of education and OMP score $\geq 6$.

Considering the importance of monitoring neural functions, we recommend the development of systematic actions that enable early diagnosis, timely treatment and prevention of physical disabilities in areas of active transmission of leprosy. In the field of clinical application, health professionals, especially doctors, physiotherapists and nurses, should take ownership of the simplified neurological assessment and use it routinely in their health services.

\section{AUTHORS" CONTRIBUTIONS}

TSM: Conceptualization, Data Curation, Formal Analysis, Project Administration, Writing - Original Draft, Writing - Review and Editing. JCM: Conceptualization, Data Curation, Formal Analysis, Project Administration, Writing - Original Draft, Writing - Review and Editing. TRMOF: Conceptualization, Data Curation, Formal Analysis, Project Administration, Writing - Original Draft, Writing - Review and Editing. CDFS: Conceptualization, Data Curation, Formal Analysis, Project Administration, Writing - Original Draft, Writing - Review and Editing.

\section{REFERENCES}

1. Brasil. Boletim Epidemiológico. Secretaria de Vigilância em Saúde. Ministério da Saúde. Hanseníase: caracterização da situação epidemiológica da hanseníase e diferenças por sexo, Brasil, 2012-2016 [Internet]. Boletim Epidemiológico. 2018;49(4):1-10. [cited on May 23, 2020]. Available from: https://antigo.saude.gov.br/images/pdf/2018/janeiro/31/2018004-Hanseniase-publicacao.pdf 
2. Bastos WM. Características sociodemográficas e epidemiológicas da hanseníase do município de Palmas - Tocantins [dissertação]. Salvador: Instituto de Saúde Coletiva, Universidade Federal da Bahia; 2017.

3. World Health Organization. Estratégia global para hanseníase 2016-2020: aceleração rumo a um mundo sem hanseníase [Internet]. Geneva: WHO library cataloguingin-publication data; 2016. 78p. [cited on May 23, 2020]. Available from: https://apps.who.int/iris/bitstream/ handle/10665/250119/9789290225607-Por.pdf;sequence=13

4. Souza CDF, Santos FGB. Prevalence of leprosy, degree II of physical incapacity and proportion of multibacillary cases: a paradox that evidences late diagnosis and hidden prevalence? Rev Epidemiol Controle Infecç. 2019;9(1):96-9. https://doi. org/10.17058/reci.v9i1.11765

5. Brasil. Ministério da Saúde/Secretaria de Vigilância em Saúde. Diretrizes para vigilância, atenção e eliminação da hanseníase como problema de saúde pública: manual técnico-operacional [Internet]. Brasília: Ministério da Saúde; 2016. [cited on May 23, 2020]. Available from: http://portalarquivos2.saude. gov.br/images/pdf/2016/fevereiro/04/diretrizes-eliminacaohanseniase-4fev16-web.pdf

6. Bahia. Diretoria de Vigilância Epidemiológica-DIVEP. Sistema de informações sobre notificação compulsória [Internet]. 2018. [cited on May 23, 2020]. Available from: http://www3.saude. ba.gov.br/cgi/tabcgi.exe?sinan/hans.def

7. Instituto Brasileiro de Geografia e Estatística (IBGE). Panorama Juazeiro BA. [Internet]. [cited on Jan 17, 2019]. Available from: https://cidades.ibge.gov.br/brasil/ba/juazeiro/ panorama/

8. Silva ME, Souza CD, Costa e Silva SP, Costa FM, Carmo RF. Epidemiological aspects of leprosy in Juazeiro-BA, from 2002 to 2012. An Bras Dermatol. 2015;90(6):799-805. https://doi. org/10.1590/abd1806-4841.201533963

9. Silva JSR, Palmeira IP, Sá AMM, Nogueira LMV, Ferreira AMR. Variáveis clínicas associadas ao grau de incapacidade física na hanseníase. Rev Cuid.2019;10(1):e618. https://doi. org/10.15649/cuidarte.v10i1.618

10. Souza CDF, Medronho RA, Magalhães MAFM, Luna CF. Modelagem espacial da hanseníase no estado da Bahia (2001-2015) e determinantes sociais da saúde. Cien Saude Colet. 2020;25(8):2915-26. https://doi.org/10.1590/141381232020258.21522018

11. Souza CDF. Hanseníase e determinantes sociais da saúde: Uma abordagem a partir de métodos quantitativos- Bahia, 2001-2015 [doutorado]. Recife: Instituto Aggeu Magalhães, Fundação Oswaldo Cruz; 2018.

12. Nobre ML, Illarramendi $X$, Dupnik KM, Hacker MA, Nery JA, Jerônimo SM, et al. Multibacillary leprosy by population groups in Brazil: lessons from an observational study. PLoS Negl Trop Dis. 2017;11(2):e0005364. https://doi.org/10.1371/journal. pntd.0005364
13. Guerrero Ml, Muvdi S, León Cl. Retraso en el diagnóstico de lepra como factor pronóstico de discapacidad en una cohorte de pacientes en Colombia, 2000-2010. Rev Panam Salud Pública. 2013;33(2):137-43. https://doi.org/10.1590/ s1020-49892013000200009

14. Castro LE, Cunha AJ, Fontana AP, Castro Halfoun VL, Gomes MK. Physical disability and social participation in patients affected by leprosy after discontinuation of multidrug therapy. Lepr Rev.2014;85(3):208-17. PMID: 25509722

15. Souza VTC, Carregosa EB, Dias SSV. Diferença na limitação de atividades em indivíduos diagnosticados com hanseníase. Cad Educ Saúde Fisioter. 2016;3(6 supl):19. https://doi. org/10.18310/2358-8306.v3n6suplem

16. Souza CDF, Fernandes TRMO, Matos TS, Ribeiro Filho JM, Almeida GKA, Lima JCB, et al. Grau de incapacidade física na população idosa afetada pela hanseníase no estado da Bahia, Brasil. Acta Fisiátrica. 2017;24(1):27-32. https://doi. org/10.5935/0104-7795.20170006

17. Diniz LM, Maciel LB. Leprosy: clinical and epidemiological study in patients above 60 years in Espirito Santo State-Brazil. An Bras Dermatol. 2018;93(6):824-8. https://doi.org/10.1590/ abd1806-4841.20187092

18. Raposo MT, Reis MC, Caminha AVQ, Heukelbach J, Parker LA, Pastor-Valero $\mathrm{M}$, et al. Grade 2 disabilities in leprosy patients from Brazil: Need for follow-up after completion of multidrug therapy. PLoS Negl Trop Dis. 2018;12(7):e0006645. https:// doi.org/10.1371/journal.pntd.0006645

19. Brasil. Ministério da Saúde. Secretária de Vigilância em Saúde. Departamento de Vigilância em Saúde. Manual de prevenção de incapacidades. 3rd ed. Brasília: Ministério da Saúde; 2008. 140p. [cited on May 23, 2020]. Available from: http://bvsms.saude. gov.br/bvs/publicacoes/manual_prevencao_incapacidades.pdf

20. Lugão HB. Avaliação ultrassonográfica de nervos periféricos em pacientes com hanseníase, antes e após o tratamento específico [doutorado]. Ribeirão Preto: Faculdade de Medicina de Ribeirão Preto; 2015.

21. Santana EMF. Deficiências e incapacidades por hanseníase na atenção secundária à saúde [mestrado] João Pessoa: Universidade Federal da Paraíba; 2017.

22. Cordeiro TL, Frade MA, Barros AR, Foss NT. Baropodometric evaluations and sensitivity alterations in plantar ulcer formation in leprosy. Int J Low Extrem Wounds. 2014;13(2):110-5. https:// doi.org/10.1177/1534734614536034

23. Gomes FG, Frade MAC, Foss NT. Úlceras cutâneas na hanseníase: perfil clínico-epidemiológico dos pacientes. An Bras Dermatol. 2007;82(5):433-7. https://doi.org/10.1590/ S0365-05962007000500006

24. Martins RJ, Carloni ME, Moimaz SA, Garbin CA, Garbin AJ. Sociodemographic and epidemiological profile of leprosy patients in an endemic region in Brazil. Rev Soc Bras Med Trop. 2016;49(6):777-80. https://doi.org/10.1590/0037-86820069-2016 